\title{
Change in Iodine Contents during Ripening of two Capsicum annuum L. Cultivars Fruits at Brazzaville, CONGO
}

\author{
I. Bafi Malonga ${ }^{1}$, A. Emmanuel Issali ${ }^{2, *}$, J. Mpika $^{3}$, Attibayeba ${ }^{4}$ \\ ${ }^{1}$ Faculty of Sciences and Techniques,PO Box 69, Marien NGOUABI University \\ Congo -Brazzaville \\ ${ }^{2}$ National Higher School of Agronomy and Forestry, Marien NGOUABI University \\ Congo-Brazzaville \\ ${ }^{3}$ Faculty of Sciences and Techniques, PO Box 69, Marien NGOUABI University \\ Congo -Brazzaville \\ ${ }^{4}$ Faculty of Sciences and Techniques, PO Box 69, Marien NGOUABI University \\ Congo -Brazzaville \\ ${ }^{*}$ Corresponding author's email : issaliemma@yahoo.com
}

\begin{abstract}
To identity iodine, assess its concentration and analyse the variation of this concentration following the ripeness stages, its titrating from Capsicum annuum L. dried fruit extract by sodium thiosulfate and starch solution test were achieved. Small and big Capsicum annuum cultivars were planted according to co mpletely randomised design onto eight rows with eight seedlings whose four was useful. One-factor Anova incorporating the means comparison according to Student-Newman-Keuls' test at 5\% level was applied. Likewise, Pearson's linear correlation at 1\%o on probability was used. Results shown that small and big Capsicum annuum L. cultivars contained iodine. People should consum Capsicum annuum $L$. fruits to avoid goiter. Other animal and plant foods also contain iodine. Iodine concentration discriminated the fruit ripeness stages in small Capsicum annuum L. cultivar. At the taste pre-ripeness stage (PMG), iodine concentration was higher than the ripe one (MG). Consequently, the consumption of its fruits is recommended at taste pre-ripeness stage to optimise the ingesting of iodine. In the same way, iodine concentration of small Capsicum annuum L. cultivar at taste pre-ripeness stage was significantly higher than the big one. At such phenological stage it will be advised people to eat small Capsicum annuum L. fruit than the big one when fruit changes. Duration of "sowing-flowering", "sowing-fruit set" and "sowing-fructification" in small Capsicum annuum L. cultivar was shorter than in the big one. Such shorter duration of small Capsicum annuum L. will allow the early obtention of its fruits than those from the big one and thus, their early selling.
\end{abstract}

Keywor ds----goiter, mental deficiency, congenital malformations, completely randomised design, groundness, sowing, fruit set

\section{INTRODUCTION}

Capsicum annuum L. is dicotyledon plant of the Solanaceae (Guyot, 1992). Asia, America and Africa yield $88.30 \%$ of the world yielding. In the World, China is the largest pepper producer with yearly average yielding of 125.000 .000 tons (Anonyme, 2006). In Republic of Congo, no information is available about the yielding as well as people dependently living of Capsicum annuum $\mathrm{L}$.

In Brazzaville several cultivars of Capsicum annuum L are cultivated and sold. Little works have been achieved on the morphological characterisation of Capsicum spp L. Among characteristics described, no information is available on the presence and quantity of iodine in pepperfruit. Indeed, iodine is micronutrient which plays an important role in human body. It allows the good functioning of thyroid gland of which the deficit triggers the goiter, mental deficiency, congenital malformations (Delange, 1998; Delange, 2000), among others.

The identification, assessment and variation of the content of iodine in Capsicum annuum L. fruit according to ripening stage in the two cultivars are poorly known. Indeed, scientific community did not pay attention to the above mentioned constraints. The solving of these constraints might help to find solutions to some pathologies such as goiter, mental deficiency, congenital malformations among others.

We hypothesise that Capsicum annuum L. fruit contains iodine and its content varies as a function of ripeness stage as well as cultivar.

The objective of this work was to identify, assess and analyse the variation of iodine content in Capsicumannuum L. fruits from two cultivars. 


\section{METHODOLOGY}

\section{Experimental Site, Climate, Soil Characteristics, Plant Material and Experimental Conditions}

Trial was conducted at experiment field of Faculty of Sciences and Techniques based on Bacongo quarter, situated at $15^{\circ} 15^{\prime} 17.3^{\prime \prime}$ West longitude, $4^{\circ} 17^{\prime} 1.7^{\prime}$ ' North latitude and 291 metres above sea. Experimentation spread out from March to September 2018. Climate is the lower Congo type characterised by two main seasons. It is about rainy season from October to May and dry season from June to September (Samba-Kimbata, 2001). Soil has particle structure and its texture is sand clay.

Plant materials consisted of two cultivars locally called "big Capsicum annuum L." and "small Capsicum annuum L." Fruit of "big Capsicum annuum" is big while the small one is effectively small. Their ripe fruits were first purchased at local market. From these, seeds were extracted, dried at laboratory then sowed in nursery. After the germination, seedlings obtained were transplanted in the experimental field according to the planned experimental design agreed.

A one-complete factor scheme in a completely randomised design was used.Factor "cultivar" with eight seedlings was laid out onto each row. In all, sixty four seedlings, accounting for sixty four treatments, were planted onto the eight rows. Experimental unit was accounted for by four seedlings, thus four useful plants, out of eight. This corresponded to sixteen useful seedlings per cultivar. They were used for measurements. Here, treatment was defined as one variant of factor "cultivar". All of treatments were carried out in quadruplicate.

Experimental area was $25 \mathrm{~m}^{2}$. At the nursery, 65 days after, seedlings regenerated from seeds were transplanted in the field. Gap between two seedlings onto the same row were 0.5 metre whereas the one between two rows was 1 metre. Plantation density was 2.56 seedlings / $\mathrm{m}^{2}$.

Planted seedlings were watered with watering can of 10 litres every day in the morning and evening. Weeds were controlled every week.

\section{Variables Measurement and Titrating of Iodine}

Growth variables and parameters obtained from iodine titrating were measured and calculated, respectively. Diameter at collar, height of seedling and number of branches were growth variables. Measurements were achieved every two weeks after the transplanting in the field. These ended at the beginning of fructification. Volumetric titrating according to Sandell-Kolthoff (1937) was applied. It consists, first, in drying, in oven at $50^{\circ} \mathrm{C}$ for 48 hours, the harvested fruits at physiological ripeness, veraison, taste, pre-ripeness and ripeness as reported Mbama et al (2018). Then these dried fruits were ground. These groundness were first mixed with distilled water then with $1 \mathrm{ml}$ of sulfuric acid (98.08 g/mole). A volume of $0.5 \mathrm{ml}$ of potassiumiodide $(1 \%)$ was added to the solution prepared. Titrating was done with sodium thiosulfate (0.012 mole per litre). At equivalence, tested yellowish solution becomes colourless. The latter was tested with starch solution to evidence the presence of iodine characterised by blue coloration. Volume of sodiu m thiosulfate (Veq) was recorded. From this, concentration of iodine $(\mathrm{Ci})$ was deducted from solutions of each groundness of cultivar fruits at different ripeness stages. Content in iodine in four phenological stages such as taste ripeness (MG), physiologic al ripeness $(\mathrm{MP})$, verais on $(\mathrm{V})$ and taste pre-ripeness $(\mathrm{PMG})$ was assessed.

\section{Statistical Analysis}

Xlstat and SPSS softwares, versions 2007 and 22.0 were used, respectively. Pearson's linear correlation at 5\% probability was used. Nonetheless, the normality of distribution of the measured variables was verified. General Linear Model of Anova freeing the investigator of respect of the distribution normality constraint at $1 \%$ level was applied.Regarding Anova, the following model, corresponding to completely randomised design was used: $\mathrm{Y}=\mu+\mathrm{T}+\varepsilon$. Where, $\mathrm{Y}$ is the response variable; $\mu$ is the general mean; $\mathrm{T}$, accounts for the treatment; $\varepsilon$, the error $\varepsilon_{i j}$ is supposed to be normally distributed with null mean and variance $\sigma 2$, that is to say, $\varepsilon_{i j} \sim \mathrm{N}(0, \sigma 2)$ (Lakhal-chaieb, 2015).

\section{RESULTS}

\section{Rele vance of Descriptors}

Variables named the volume of sodium thiosulfate and iodine concentration were very highly correlated $(\mathrm{r}=$ $1 * * * * *$; p-value $<0.00001$; table 1). Coefficient of correlation of the fitted curve $\left(\mathrm{R}^{2}\right)$ was $100 \%$. Consequently, the choice was focused on the iodine concentration. The latter was used for the rest of work. 
Table 1. Linear relationship between sodium thiosulfate volume and iodine concentration.

Legend.

\begin{tabular}{cccc}
\hline $\begin{array}{c}\text { Dependent } \\
\text { variable }\end{array}$ & Criterion & Veq* $^{*}$ & Ci* $^{*}$ \\
\hline Veq & Pearson's correlation & 1 & $1.000^{* * * * *}$ \\
& p-value & & $<0.00001$ \\
$\mathrm{~N}^{*}$ & 32 & 32 \\
\hline $\mathbf{C i}$ & Pearson's correlation & $1.000^{* * * * *}$ & 1 \\
& $\mathrm{p}$-value & $<0.00001$ & \\
& $\mathrm{~N}^{*}$ & 32 & 32 \\
\hline
\end{tabular}

Veq* : Volume at equivalence of sodium thiosulfate. Ci*: Concentration of iodine. $\mathbf{N}^{*}$ : Size of treatments. Value accompanied by three asterisks reveals that the correlation is very highly significant, namely at $1 \% 00$ likelihood.

Effect of ripeness stage on the expression iodine concentration in fruit of each of two cultivars

Iodine concentration was discriminating enough to structure the variants of factor "Ripeness stage" into distinct sub-sets. Sure enough, the variation of "Ripeness stage" induced the variation of iodine concentration. This one can be structured into distinct groups ( $\mathrm{p}$-value $=0.035$; table 2 ).

Two sub-sets were evidenced. First, accounted for taste ripeness (MG), was characterised by low iodine concentration $($ Mean $=0.007$ mole per litre). Second, known as taste pre-ripeness (PMG), was marked by high iodine concentration $($ Mean $=0.0110$ mole per litre). Coefficient of variation stretched out from 9.09 to $14.29 \%$ (Table 3).

Moreover, two classes were identified. Firstly, composed of big Capsicum annuum L cultivar, was singular in low iodine concentration (Mean : 0.0075 mole per litre). Secondly, consisted of small Capsicum annuum L., was distinguished by high iodine concentration (Mean : 0.011 mole per litre). This corresponded to real gap of 0.0035 mole per litre (Table 4). Magnitude of variation was 13.09 and $15.53 \%$, respectively (Table 4).

Table 2. Assessment of factor "Ripeness stage" on the expression of iodine concentration by means of analysis of variance.

\begin{tabular}{|c|c|c|c|c|c|c|c|c|c|c|}
\hline \multirow{2}{*}{$\begin{array}{c}\text { Source } \\
\text { Cultivar }\end{array}$} & \multicolumn{2}{|c|}{ SS* } & \multicolumn{2}{|c|}{ df* } & \multicolumn{2}{|c|}{ MS* } & \multicolumn{2}{|c|}{$\mathbf{F}^{*}$} & \multicolumn{2}{|c|}{ p-value* } \\
\hline & Small & Big & Small & Big & Small & Big & Small & Big & Small & Big \\
\hline $\begin{array}{c}\text { Corrected } \\
\text { model }\end{array}$ & 0.00005 & 0.00003 & 3 & 3 & 0.00002 & 0.00001 & 4.000 & 1.645 & 0.035 & 0.231 \\
\hline Intercept & 0.00100 & 0.00100 & 1 & 1 & 0.00100 & 0.00100 & 264.000 & 213.774 & 0.000 & 0.000 \\
\hline $\begin{array}{l}\text { Ripeness } \\
\text { stage }\end{array}$ & 0.00005 & 0.00003 & 3 & 3 & 0.00002 & 0.00001 & 4.000 & 1.645 & 0.035 & 0.231 \\
\hline Error & 0.00005 & 0.00007 & 12 & 12 & 0.00000 & 0.00001 & & & & \\
\hline Total & 0.00100 & 0.00100 & 16 & 16 & 0.00010 & & & & & \\
\hline $\begin{array}{c}\text { Corrected } \\
\text { total }\end{array}$ & 0.000099 & 0.000098 & 15 & 15 & & & & & & \\
\hline
\end{tabular}

Legend.

SS*: Sum of squares. df* : Degree of freedom. MS* :Mean square. F* : Fisher-Snedecor's test statistics. p-value : Critic al level.

Table 3. Classification of means of the iodine concentration as a function of ripeness stage from two cultivars.

\begin{tabular}{ccc|llc}
\hline \multicolumn{2}{c|}{ Small Capsicum annuum } & \multicolumn{3}{c}{ Big Capsicum annuum } \\
\hline $\begin{array}{c}\text { Ripeness } \\
\text { stage* }\end{array}$ & Mean Ci* & $\begin{array}{c}\text { CV } \\
(\%)\end{array}$ & $\begin{array}{l}\text { Ripeness } \\
\text { stage }\end{array}$ & Mean Ci* & $\begin{array}{c}\text { CV } \\
(\%)\end{array}$ \\
\hline MG & $0.0070 \mathrm{a}$ & 14.29 & MP & $0.0075 \mathrm{a}$ & 10.00 \\
MP & $0.0080 \mathrm{ab}$ & 12.50 & PMG & $0.0075 \mathrm{a}$ & 12.50 \\
V & $0.0080 \mathrm{ab}$ & 12.50 & MG & $0.0098 \mathrm{a}$ & 12.50 \\
PMG & $0.0110 \mathrm{~b}$ & 9.09 & V & $0.0105 \mathrm{a}$ & 9.09 \\
\hline
\end{tabular}

Legend.

Ripeness stage*. MG : Taste ripeness. MP : Phy siological ripeness.V: Veraison. PMG: Taste pre-ripeness. Ci*: Concentration of iodine. CV $(\%)^{*}$ : Coefficient of variation in percentage. Numbers followed by the same letter in column are not significantly different according to Student-Newman-Keuls' test at 5\% likelihood. 
Table 4. Variation of iodine concentration in fruits of the big and small Capsicumannuum cultivars at taste pre-ripeness

\begin{tabular}{ccc}
\multicolumn{3}{c}{ stage. } \\
\hline Cultivar & Mean* & CV \% \\
\hline Big & $0.008 \mathrm{a}$ & 13.09 \\
Small & $1.875 \mathrm{~b}$ & 15.53 \\
\hline
\end{tabular}

Legend.

Mean*: Values followed by the same letter in column are not significantly different after the Student's two-samples t testat $1 \%$ likelihood.

\section{Phenological stages in the two Capsicum annuum cultivars}

In the two cultivars, the seed emergence of the seedlings majority and transplanting in the field had comparable durations. These were 7 and 65 days, for interval between sowing and seed emergence as well as from sowing to transplantation in the field, respectively. In constrast, when we consider the duration of flowering, fruit set and fructification, values of big Capsicumannuum were above of those from small Capsicumannuum. Indeed, big Capsicumannuumrecorded 88, 103and 128 daysafter sowing for flowering, fruit set and fructificationas against 76, 96 and 115 days concerning small Capsicum annuum cultivar, respectively (Table 4).

Table 4. Duration of phenological stages of seedlings from two tested Capsicumannuum cultivars.

\begin{tabular}{ccc}
\hline Phenological stage & \multicolumn{2}{c}{ Duration (day after sowing) } \\
\cline { 2 - 3 } & $\begin{array}{c}\text { Small Capsicum } \\
\text { annuum }\end{array}$ & $\begin{array}{l}\text { Big Capsicum } \\
\text { annuum }\end{array}$ \\
\hline Sowing & - & - \\
Seed emergence & 7 & 7 \\
Transplantating & 65 & 65 \\
Flowering & 76 & 88 \\
Fruit set & 96 & 103 \\
Fructification & 115 & 128 \\
\hline
\end{tabular}

\section{DISCUSSION}

Iodine was identified in fruit of big and small Capsicum annuum L. cultivars. Its concentration was assessed and analysed. To our knowledge no information is available concerning titrating of iodine in Capsicum annuum L. cultivars fruit. Nevertheless, Von Fellenberg (1930), Dunn et al., (1993), Anonyme (https://fr.wikipedia.org/wiki/Teneur en iode des aliments, accessed on 2 nd September 2019) reported works on milk, urine and some foods. Our works shown that, first, iodine exists in fruits of the two Capsicum annuum L. cultivars. Likewise, small Capsicumannuum L. cultivar displayed higher iodine concentration at taste pre-ripeness stage.

Iodine is present in Capsicum annuum L. fruits of the two cultivars (Table 2). Indeed, titrating of iodine from Capsicum annuum L. dried fruit extract by sodium thiosulfate and starch solution test were positive. In other plant and animal materials, the presence of iodine was also revealed Anonyme (https://fr.wikipedia.org/wiki/Teneur en iode des aliments, accessed on 2 nd September 2019). From this, we advise people to eat fruits of Capsicum annuum $\mathrm{L}$. to ingest iodine and, thus, to prevent goiter.

Variable "iodine concentration" was the most relevant (Table 1). Sure enough, sodium thiosulfate is only reagent which allowed to titrate iodine in Capsicum annuum $\mathrm{L}$ fruits. Thus, that is the concentration of iodine which is the most important variable. Issali et al., (2008) used the Principal Component Analysis to identify relevant variables. Here, we identified iodine concentration as the most relevant variable than sodium thiosulfate volume by means of Pears on's linear correlation. In the future, we will use iodine concentration to describe populations of plant or animal species.

In small Capsicum annuum L. cultivar, iodine concentration discriminated the fruit ripeness stages. At the taste pre-ripenessstage (PMG), iodine concentration was higher than the ripe one (MG). Probably, concentration in secondary metabolites would be more important in pre-ripeness stage than the ripe one. In tomato and pepper, iodine content is 0.10 $\mu \mathrm{g} / 100 \mathrm{~g}$ and $0.12 \mu \mathrm{g} / 100 \mathrm{~g}$, respectively (Haldimann et al., 2005; Leufroy et al., Rose et al., 2001). Therefore, the consumption of small Capsicum annuиm L. fruit is recommended at taste pre-ripeness stage to optimise the ingesting of iodine and thus, to avoid goiter.

In the same way, statistically, iodine concentration of small Capsicum annuum L. cultivar at taste pre-ripeness stage was upper than the big one. This might find an explanation through the iodine metabolism which would be more active in small Capsicum annuum L. cultivar than in the big one. Iodine content increased from physiological maturity to taste maturity then again decreased. Thus, at taste pre-ripeness stage it will be preferable to eat small Capsicum annuum $\mathrm{L}$. fruit than the big one when fruit changes.

The duration "sowing-seed emergence" and "sowing-transplantation" was comparable for the two cultivars. In contrast, duration of "sowing-flowering", "sowing-fruit set" and "sowing-fructification" differed in the two cultivars. The latter could find an explanation through the difference in genetic constitution, and thus the product of genes activity would 
be different. The duration "sowing-transplantation" and "sowing-fructification" is 40-45 days after sowing and 105-130 days after sowing respectively (Fondio et al, 2009). The cultivation of small Capsicumannuum L. allows the early obtention of the fruits and thus, their early selling.

\section{CONCLUSION}

We hypothesised that Capsicum annuum L. fruit contains iodine and its concentration varies as a function of ripeness stage as well as cultivar. According to our obtained results, the two Capsicumannuum L. cultivars contain indeed iodine. This one varies after the phenological stages in small Capsicum annuum fruits. Nonetheless, no difference was noted on these two cultivars.

Iodine is present in Capsicum annuum L. fruits of the two cultivars. It would be desirable that people to eat fruits of Capsicum annuum to ingest iodine.

Iodine concentration was the most relevant variable. In the future, we will use iodine concentration to describe populations of plant or animal species.

In small Capsicum annuum L. cultivar, iodine concentration discriminated the fruit ripeness stages. At the taste pre-ripeness stage (PMG), iodine concentration was higher than the ripe one (MG).The consumption of small Capsicum annиит L. fruit is recommended at taste pre-ripeness stage to optimise the ingesting of iodine. In the same way, iodine concentration of small Capsicum annuum L. cultivar at taste pre-ripeness stage was higher than the big one. Therefore, at taste pre-ripeness stage it will be preferable to eat small Capsicum annuum L. fruit than the big one when fruit changes. Iodine content increased from phyiological maturity to taste maturity then again decreased.

Duration of "sowing-flowering", "sowing-fruit set" and "sowing-fructification" differed in the two cultivars. The cultivation of small Capsicum annuиm L. allows the early obtention of the fruits and thus, their early selling.

\section{REFERENCES}

- Anonyme, 2006. Activité de Renforcement de la Commercialisation Agricole en Guinée (ARCA) la filière petit piment de Guinée, 32p.

- Anonyme2. https://fr.wikipedia.org/wiki/Teneur_en_iode_des_aliments. Accessed on 2nd September 2019. Page of the online encyclopedia providing informations about 22 animal and plant foods.

- Mbama O., Mpika J., Andzouana M., and Attibayéba., 2018. Variation des teneurs en composés phénoliques au cours de la maturation des fruits de Grewia coriacea. International Journal of Innovation and Applied Studies, 24 : 1849-1858.

- $\quad$ Delange F., 2000. The role of iodine in brain development.Proc.Nutric.Soc. 59: 75-79.

- Von Fellenberg T.,1930. Le dosage de l'iode dans le lait. Le lait, INRA Editions, Hal-00895002, 10 (99) : 986989.

- Delange F., 1998. Screening for congenital hypothyroidism used as an indicator of degree of iodine deficiency and diets control, Thyroid, $8: 1185-1192$.

- $\quad$ Dunn J.T., Crustchied, Gutekunst R., Dunn A.D., 1993. Méthodes de dosage de l'iode dans les urines, ICCCIDD/UNICEF/OMS, 4p.

- Fondio L, Koumé C, Djidji A, Hortense et Aidara S., 2009. Bien cultiver le piment en côte d'ivoire. Fiche technique, $4 \mathrm{p}$.

- Guyot M. 1992. Systématique des angiospermes : référence à la flore du Togo. Edition financée par la Mission Française de Coopération et d'Action Culturelle de Lomé. Diffusion auprès de la bibliothèque de l'Université du Benin. Togo.p 141.

- Haldimann M, Alt A, Blanc A, Blondeau K (2005). Iodine content of food groups. J Food Compos Anal, (https: //doi.org/j.jfca.2004.06.003), 18(6): 461-71.

- Issali A.E., Traore A., Koffi K.E., N'goran K.A.J., Sangaré, A..(2008). Characterization of callogenic and embryogenic of some genotypes of cocoa (Thebroma cacao L.,) under selection in côte d'Ivoire, Biotech, 7 (1): 51-58. 
- Leufroy A, Noel L, Bouisset P, Maillard S, Bernagout S, Xhaard C et al. (2005). Determination of total iodine in French Polynesian foods: method validation and occurrence data. Food Chem.169: 13440(https://doi.org/10.1016/j.foodchem.2014.07.142).

- OMS/UNICEF/ICCIDD. Assessment of iodine deficiency disorders and monitoring their elimination: a guide for programme managers, 3ième edition. Genève: Organisation mondiale de la santé; 2007 (http:// whqlibdoc.who.int/publications/2007/9789241595827.

- Rih. A., S. Moulessehoul., M. Benali. Dosage de l'iode chez les enfants scolarisés dans la religion de Sidi Bel Abbés.

- Rose M, Miller P, Baxter M, Appleton G, Crews H, Croasdale M (2001). Bromine and iodine in 1997 UK total diet study samples, (https://doi.10.1039/b105695f), J Environ Monitor. 3(4): 361-365

- Rohner F, Zimmermann M, Jooste P, Pandav C, Caldwell K, Raghavan R et al.(2014).Biomarkers of nutrition for development: iodine review,(https://doi.org/10.3945/jn.113.181974), J Nutr.144 (8): 1322S-1342S.

- Samba-Kimbata M.J et Mpounza M.2001. Atlas du Congo : climat, 2ème Eds de l'Afrique. Paris, aguar, 76 : 14-18. 